\title{
ADVANTAGES OF JOINING A NETWORK OF SMALL AND MEDIUM ENTERPRISES (SMES): NATIONAL (BRAZIL) VERSUS INTERNATIONAL LITERATURE REVIEW
}

\section{VANTAGENS DE ADERIR A UMA REDE DE PEQUENAS E MÉDIAS EMPRESAS (PMES): ANÁLISE DA LITERATURA NACIONAL VERSUS INTERNACIONAL}

Sandro César Bortoluzzi

Doutor em Engenharia de Produção (UFSC), Professor da UTFPR Campus Pato Branco.

Pato Branco, PR, Brasil

E-mail: sandro@utfpr.edu.br

Sandra Mara lesbik Valmorbida *

Mestra em Contabilidade (UFSC), Professora da UTFPR Campus Pato Branco.

Pato Branco, PR, Brasil

E-mail: smiesbik@gmail.com

Sandra Rolim Ensslin

Doutora em Engenharia de Produção (UFSC), Professora da Universidade Federal de Santa Catarina.

Florianópolis, SC, Brasil

E-mail: sensslin@gmail.com

Leonardo Ensslin

Doutor em Engenharia de Produção (UFSC), Professor da Universidade Federal de Santa Catarina.

Florianópolis, SC, Brasil

E-mail: leonardoensslin@gmail.com

\section{RESUMO}

O objetivo deste artigo é mapear os principais estudos, publicados na literatura nacional e internacional, sobre redes de Pequenas e Médias Empresas (PMEs), a fim de consolidar os diferentes pontos de vista sobre as vantagens de se aderir a uma rede de empresas. Para isso, foi selecionado, por meio de um processo estruturado, um portfólio bibliográfico. Este estudo, de caráter descritivo e bibliográfico, concluiu que as vantagens apresentadas por pesquisadores, em ambos os contextos, são congruentes e complementares: ganhos no aspecto gerencial, desenvolvimento conjunto de novos produtos, redução de custos, acesso a novos mercados, acesso a mão de obra especializada - e importantes para a melhoria da competitividade das PMEs.

Palavras-chave: Redes organizacionais. Revisão de literatura. Pequenas e médias empresas (PMEs).

Data de submissão: 16 de maio de 2014.

\section{ABSTRACT}

The main goal of the paper is to map the main studies, published in the national and international literature, on SMEs networks in order to consolidate the different views on the advantages of joining a network of companies. For this purpose, it was selected by means of a structured process, a Bibliographic portfolio (BP). This study of descriptive and bibliographic character concluded that the shown advantages by researchers, in both contexts, are congruent and complementary - gains in the managerial aspects, joint development of new products, cost reduction, access to new markets, access to specialized workers - and important for the improvement of the SMEs competitiveness.

Keywords: Inter-firm network. Literature review. Small and medium enterprises (SMEs).

Data de aprovação: 4 de junho de 2016. 


\section{INTRODUCTION}

Small and Medium Enterprises (SMEs) perceived substantial changes in the competition for the market in recent decades. Many of them understand that their market, before captive, is now a target for larger and more organized foreign competitors (DAMASKOPOULOS et al., 2008).

In addition to increased competition, SMEs have access, usually problematic, to sophisticated equipment, technology services, professional training, efficient structure for purchasing inputs and sale of products. In other words, SMEs coexist with capacity constraints and higher economic resources compared with larger competitors (WEGNER; MISOCSKY, 2010).

However, SMEs have sought alternatives to face the difficulties imposed by the management and market aspects, being that one of the alternatives is the insertion into networks of small and medium enterprises or production arrangements (CAMARINHA-MATOS; ABREU, 2007; VILLA, 2007).

The researches related to cooperation between enterprises and the establishment of interorganizational relationships stand out at the moment they become an important alternative for many enterprises, especially for small and medium sized businesses that need to adapt to the changing scenario and to the demands of new capacities and skills (VERSCHOORE; BALESTRIN, 2008).

Despite recognizing that adhering to a network of enterprises is important for the improvement of SMEs' competitiveness, each study brings in a partial form, the advantages of that adhesion. In each survey, the author points out some advantages of being part of a network of cooperation between SMEs, but it can be seen in each study a different and/ or complementary view, without a thorough analysis on the topic.

In this context, the research question emerges: What are the advantages pointed out in national and international literature for SMEs to join a network of cooperation? To answer this question, we defined the following research goal: to map the studies main networks of SMEs, in order to consolidate the different views on the advantages of joining a network of SMEs to achieve the overall objective; there were defined the following specific objectives: (i) carry out a structured process to select the articles that are more closely aligned with the subject, (ii) consolidate the main advantages cited in the literature to join a network of enterprises, and (iii) compare the advantages related to internal and external organizational contexts of selected publications.

The article presents the following: (i) theoretical reference, (ii) research methodology, (iii) presentation and discussion of results, and (iv) closing remarks.

\section{THEORETICAL REFERENCE}

First, it shows the concept of enterprises' network. However, the task is not easy because there are several concepts in the literature and different visions of what is, and what is the purpose of cooperation networks. However, the conceptual distinctions that arise in the literature on local production systems are reduced to varying degrees of development, of integration of the production chain, of articulation and of interaction between agents and local institutions, and of systemic capacities for innovation (SUZIGAN, 2001).

However, for the purposes of this work, cooperation networks are geographic concentrations of interconnected enterprises, specialized suppliers, service providers, firms in related industries and associated institutions in a particular field that compete but also cooperate (PORTER, 1998). 
The topic enterprises' network has motivated several studies during the last years (SUZIGAN, 2001). Some researchers have as a focus the study of public policies related to the formation of PMEs networks (SUZIGAN, 2001); other authors focus on the SMEs network management through the Evaluation of the Organizational Performance (BURLAT et al., 2003; BITITCl et al., 2004; PETTAN, 2005; GRANDO;BELVEDERE, 2006; VILLA, 2007; CARPINETTI et al., 2007; BITITCI et al., 2007; CARPINETTI et al., 2008; HANSEN; OLIVEIRA, 2009; PARRILLI, 2009; JAHN, 2009; WEGNER; MISOCSKY, 2010). Some other studies deal with the formation of SMEs networks and their contribution to regional development (SUZIGAN, 2001), from, among other researches on the topic (MARTINKENAITE, 2011; CHAO, 2011).

The studies related to the formation of SMEs networks arise from limitations that SMEs face due to the limited size of insufficient human and financial resources, and other factors that prevent SMEs from facing the innovation policies envisage only by their internal skills (PEREIRA; VENTURINI, 2006).

Another factor which limits the development of SMEs refers to the management standpoint. Surveys conducted in Brazil indicate that the vision of business management is hardly implemented in SMEs (SUZIGAN, 2001).

In addition to the aforementioned limitations, SMEs have difficulty in entering the international market, and is an accepted fact that in the 21st century, the competition is made between enterprises that efficiently and effectively integrate their skills and resources to compete in a global economy (BITITCl et al., 2004). Besides the difficulty in entering the global market, SMEs present limitations for consolidation in the local market. Opening new markets is influenced by the fast development of technology and by the need to integrate different technologies. Isolated small companies rarely have enough influence to maximize the efficiency and to minimize the cost, and consequently, many struggle to find enough capital of investment to upgrade or expand their portfolio. Small enterprises are recognized as being flexible and receptive to customers and to market opportunities, but their size means they are especially vulnerable to resource constraints. Many small enterprises close within a few years of their creation, and the lack of resources is often cited as the main factor (WELSH; WHITE, 1981).

Thus, the literature indicates that SMEs should join networks of cooperation to overcome these limitations (GEROLAMO et al., 2008; HANNA; WALSH, 2008; CAMPO; ALBARRACÍN, 2008). Some studies of the formation of regional clusters highlight the improved stability of SMEs belonging to clusters. The reason lies in the collaborative activities carried out within a district that covers different aspects of SMEs and that has not always directly measurable results in economic and financial terms (ANTONELLI; CAROLEO, 2011).

In a global economy, enterprises are trying to reinvent their business and maintain their competitive advantage through collaboration that has been discussed as a path for organizations in situations where working alone is not sufficient to achieve the desired ends (BITITCl et al., 2007). SMEs belonging to networks are often more competitive and innovative than those operating in isolation. By working jointly, SMEs can increase their focus through specialization in functions that are complementary within their networks (BITITCI et al., 2007). 


\section{RESEARCH METHODOLOGY}

This section is organized as follows: (i) methodological framework; (ii) procedures for bibliographic search, and (iii) procedures for data analysis.

\section{Methodological Framework}

In relation to the objective, this research is of descriptive nature (GIL, 1999), because it seeks to map and analyse the characteristics of a bibliographic portfolio (PB) on the national and international advantages for SMEs to join a cooperation network and consolidate the view of the authors (GIL, 1999). The nature of the study is theoretical, since it seeks to consolidate the information contained in the literature about the benefits that SMEs get when they join a SMEs network (RICHARDSON, 2008). The data used in research are secondary because the articles published in national and international networks on the topic of SMEs networks were analysed (RICHARDSON, 2008). Thus, the used survey instrument was the document analysis, that is, journal articles (GIL, 1999). Regarding the approach of the problem, the research is features (RICHARDSON, 2008), since the made analysis includes the meeting of the advantages mentioned by the authors in relation to participating in a cooperative network.

\section{Procedures for bibliographic search}

The literature search was performed in national and international journals through two structured processes. First, we present the process used to select the Bibliography Portfolio (BP) of published researches in international journals. The procedure used Knowledge Development Process- Constructivist - ProKnow-C, used in several scientific researches (TASCA et al., 2010; BORTOLUZZI et al., 2010; ROSA et al., 2011; AFONSO et al., 2011; BORTOLUZZI et al., 2011ab; LACERDA et al., 2011; LACERDA et al., 2012; BRUNA JUNIOR et al., 2012).

To form the BP of the research topic, the process was divided into two main phases: (i) selection of the database (DB) of gross articles, and (ii) filtering of the articles database. The first phase, selection of the database of gross articles, is subdivided, in turn, into three stages, namely: (i) define keywords, (ii) establish databases and (iii) search articles in databases with the keywords. The second phase, the filtering database of articles, is subdivided, in turn, into five stages, namely: (i) elimination of repeated articles, (ii) alignment by reading the title, (iii) alignment on the scientific recognition; (iv) alignment by reading the summary, and (v) alignment by reading the full article

Database selection of gross articles

To meet the phase 'database selection of gross articles ' to form the bibliographic portfolio about networks of SMEs, initially were defined the lines of research and the keywords for each axis (first step). From the definition of the key words, all possible combinations between the keywords of the search axes were formed. It is noted that the search was conducted through the 90 possible combinations of keywords using the 
Boolean AND expression that indicates that the return of articles happens when the three keywords appear in the search fields.

In the development of the second stage, initially, it has been set up the database (DB) to carry out the research. As a criterion for selection of $D B$, the following aspects were established : (i) the DB should be included in the portal's journal of the regular Coordination of Improvement of Higher Education Personnel (CAPES), (ii) to be chosen, the DB should be in one of the following three major areas of CAPES: Applied Social Sciences, Engineering and Multidisciplinary area, because these three areas are closely aligned with the topic illustrated in the research, (iii) the DB should provide a tool of search with the possibility of using Boolean expressions (iv) the search engine of the DB should provide the ability to search in the fields: title, abstract and keywords. Thus, 23 DB met the established criteria. As a result, it was verified the alignment of keywords in the DB, that is, it was sought the number of articles for the combinations of keywords. Thus, it was possible to fix the desired representation, that is, to decide the amount of DB that would be researched. With the made analysis, it was decided to keep looking in all related DB.

The third step consisted of conducting the search in each DB through keywords combinations. It is noted that the fields of search were: title, abstract and article keywords. It is also noteworthy that the search was not restricted in relation to the period of time, that is, it was sought the data range provided by DB. This process resulted in the primary gross articles database of 3375 articles. Finally, for completion of the phase: database selection of gross articles to form the gross BP on SMEs Networks, it was performed the test of adherence of these keywords. The goal here is to verify the need for incorporation of new keywords to ensure an aligned BP. For this purpose, it was proceeded to the reading of the found articles' titles; all the keywords of the articles were collected and compared with the keywords used in the initial search. With the completion of this process, it was found that there was no need to incorporate new keywords. So, it was passed to the development of the next phase.

\section{Filtering of articles database}

The first stage in the phase of filtering the database of articles refers to the importation of articles for a software of bibliographic management. Thus, there were imported for the Endnote software 3375 articles out of the gross articles database. After the importation, the software allows the exclusion of repeated items. Thus, there were excluded 2289 repeated articles, and remained 1086 non-repeated articles.

The next step was the reading of the 1086 titles in order to check the alignment of the articles to the research topic. It is noted that at in this stage it was sought to delete the articles that had total misalignment with the research topic; in doubt, the article was kept for further analysis of the next steps. As a result of the reading process, 501 articles remained aligned to the research topic. Similar procedures were followed/viewed/noticed in the articles by Nascimento et al. (2010) and Mondo and Fiates (2014).

The next step consists in identifying the scientific recognition of the articles. In this process, the scientific recognition is measured by citations in other scientific studies, so it was identified the number of times each article was cited. For standardization purposes, it was sought the amount of citations of each article in the "Google academic". The result of this step was the identification of 215 articles with the highest scientific recognition ( $97 \%$ of citations) and 286 with less scientific recognition ( $3 \%$ of citations). 
The next step consisted in conduct the reading of 215 abstracts of articles with the highest scientific recognition in order to verify the alignment of the article with the topic. In addition to the 215 articles, 27 articles of the references were included to the BP on the basis of the test of their representativeness. After this step, remained 57 articles that were "saved" in the A repository. As a result, the articles were filtered with less scientific recognition, that is, the 286 articles (separated in the previous step) were analysed in order to verify if the article was recent and if the author is present in the A repository. With this analysis and reading of these abstracts, 17 articles that were "saved" in the B repository were identified. To finish this step, the articles "stored" in the A (57 items) and B (17 articles) repositories were joined, forming a single repository, called C, consisting of 74 articles.

The final step of filtering the articles database consisted in making the filter for alignment of the entire article. The result of this step was the selection of 21 articles that make up the International BP.

In relation to the search in national journals, this occurred in national journals in the field of Management, Accounting and Tourism and Engineering III, classified as Qualis Stratum A1 to B5 by the Coordination of Improvement of Higher Education Personnel (CAPES-Brazil). It should be noted that the search occurred in selected journals and there was no restriction on the researched period, that is, the search happened in all available editions in each journal. There were surveyed 408 scientific journals where 668 general articles on the topic enterprises' network. As a result, there was a reading of 668 abstracts, being that 55 articles aligned to the topic were identified. Then, it was made the full reading of the 55 articles to verify which were fully aligned to the topic of SME Network Management After reading the 55 articles, there were selected 33 aligned articles, and 22 were excluded for misalignment. Thus, 33 articles are part of the national $\mathrm{BP}$ to perform the research.

\section{Procedures for data analysis}

It was sought to build a mapping of the articles in order to draw on each author's vision, the advantages of joining a network of enterprises. It should be noted that the procedures for carrying out the mapping of the BP articles was the same for the national and for the international BP. The aim of the mapping is to extract the articles of the national BP and of the international literature related to the benefits of being part of a SMEs network.

To perform the mapping of the 21 articles out of the international BP and out of the 33 national articles, it was proceeded with the reading of these articles and it was extracted the vision of each author about the advantages of being part of a network of enterprises. This information was recorded in a spreadsheet, sorted by a sequential number of each work, the authors' names, year of publication, the journal where the article was published and a column with the advantages of joining the network of enterprises. There were formulated two electronic spreadsheets, one for the analysis of the articles of international bibliographic portfolio (21 articles) and one for the national bibliographic portfolio. 
PRESENTATION AND DISCUSSION OF RESULTS

The mapping of the articles published in international journals allowed to identify the advantages of participating in networks of SMEs, as the examples in Chart 1.

Chart 1 - Advantages of being part of a network of SMEs

\begin{tabular}{|c|c|}
\hline Importance/advantages of being part of a network of enterprises (international portfolio) & $\begin{array}{l}\text { Author(s) of the } \\
\text { article in the BP }\end{array}$ \\
\hline Increase their market share and increase asset utilization. & Bititci et al. (2004) \\
\hline $\begin{array}{l}\text { Share resources and information, reduce risks, cost and time of placing new products on the } \\
\text { market. }\end{array}$ & Bititci et al. (2007) \\
\hline $\begin{array}{l}\text { Economy of scale for purchasing and supply, joint production and sharing of services and } \\
\text { business, solutions for common problems and exchange of knowledges. }\end{array}$ & Burlat et al. (2003) \\
\hline $\begin{array}{l}\text { Share costs, share risks, reduce the level of dependence on third parties; increase the capacity } \\
\text { for innovation; defend/ increase a market position, increase flexibility. }\end{array}$ & $\begin{array}{l}\text { Camarinha-Matos } \\
\text { and } \\
\text { Abreu (2007) }\end{array}$ \\
\hline $\begin{array}{l}\text { Specialization of hand labour, easy access to input suppliers and to specialized services and } \\
\text { rapid diffusion of new knowledge. These advantages are called external economy, because it } \\
\text { can help to reduce costs for firms in cluster. }\end{array}$ & $\begin{array}{l}\text { Carpinetti et al. } \\
\text { (2008); Carpinetti } \\
\text { and Oiko (2008). }\end{array}$ \\
\hline $\begin{array}{l}\text { Core of specialized workers, easy access to input suppliers and to specialized services, and } \\
\text { rapid dissemination of new knowledge. }\end{array}$ & $\begin{array}{l}\text { Gerolamo et al. } \\
(2008)\end{array}$ \\
\hline An individual enterprise could share skills that have not been perceived yet. & $\begin{array}{l}\text { Hanna e Walsh } \\
(2008)\end{array}$ \\
\hline $\begin{array}{l}\text { Collaboration between companies have become important tools for business management to } \\
\text { improve business competitiveness. }\end{array}$ & $\begin{array}{l}\text { Hoffmann and } \\
\text { Schlosser (2001) }\end{array}$ \\
\hline Importance/advantages of being part of enterprises network (national portfolio-Brazil) & $\begin{array}{l}\text { Author(s) of the } \\
\text { article in the BP }\end{array}$ \\
\hline Training programs, organization of fairs, courses and seminars, and by the integration of skills. & $\begin{array}{l}\text { Galdámez et al. } \\
(2009)\end{array}$ \\
\hline $\begin{array}{l}\text { Inter-organizational relationships lead to the possibility of relational returns, which can not be } \\
\text { generated by any of the organizations individually. }\end{array}$ & $\begin{array}{l}\text { Wegner and } \\
\text { Misocsky } \\
(2010)\end{array}$ \\
\hline $\begin{array}{l}\text { Seeking new markets, lowering costs, sell as a group, create and develop new products and } \\
\text { more efficient production processes, increase the productive capacity of the company, } \\
\text { participate in innovation projects, improve the company image, plan joint purchases and create } \\
\text { differential against the competition. }\end{array}$ & $\begin{array}{l}\text { Rezende and } \\
\text { Serpa } \\
\text { (2009); } \\
\text { Gobbo Junior et } \\
\text { al. (2006) }\end{array}$ \\
\hline $\begin{array}{l}\text { The collaboration with other enterprises causes them to develop sustainable competitive } \\
\text { advantage by the creation of value. }\end{array}$ & $\begin{array}{l}\text { Faccin et al. } \\
(2009)\end{array}$ \\
\hline Reduction of costs, economy of resources, access to new markets, new technologies. & Adam et al. (2008) \\
\hline Access to information, resources, markets and technologies. & Mais et al. (2010) \\
\hline $\begin{array}{l}\text { Increasing the bargaining power in negotiations with their suppliers and customers and also } \\
\text { allows the interaction between the agents involved in the production process, which in turn } \\
\text { generates an overflow of knowledge to all individual firms. }\end{array}$ & $\begin{array}{l}\text { Silva and Hewings } \\
(2010)\end{array}$ \\
\hline $\begin{array}{l}\text { Gain of collective efficiency. It is agreed that the joint action of a group of enterprises in the } \\
\text { same industry brings benefits to local economic development and sustainability of these } \\
\text { enterprises. }\end{array}$ & $\begin{array}{l}\text { Marion Filho and } \\
\text { Sonaglio }(2010)\end{array}$ \\
\hline $\begin{array}{l}\text { Freitas (2001), opening the view that cooperative relationships are also possible and able to } \\
\text { leverage a lot the profitability of an enterprise, as they can reduce costs along the chain and } \\
\text { also ensure better service levels to customers. }\end{array}$ & $\begin{array}{l}\text { Farias and Ramos } \\
\text { (2009) }\end{array}$ \\
\hline To promote the generation, acquisition and dissemination of knowledge and innovations. & $\begin{array}{c}\text { Galão and } \\
\text { Camara (2009) }\end{array}$ \\
\hline $\begin{array}{l}\text { Access to inputs, specialized personnel and information, complementarities between the } \\
\text { activities of various participants, access to institutions and to public properties. }\end{array}$ & $\begin{array}{l}\text { Mazzaro et al. } \\
(2009)\end{array}$ \\
\hline Competitive advantages of global reach. & $\begin{array}{l}\text { Martins et al. } \\
(2009)\end{array}$ \\
\hline $\begin{array}{l}\text { Create favourable conditions to overcome barriers - technological, financial } \\
\text { the sharing of risks. }\end{array}$ & $\begin{array}{l}\text { Souza and Ferraz } \\
(2007)\end{array}$ \\
\hline
\end{tabular}

Source: Elaborated by the authors.

From the information contained in Chart 1 is possible to consolidate the benefits resulting from participation in collaborative network. 
Figure 1 presents the information's about the advantages of joining a network, in order to guide the comparison between the international and national contexts.

Figure 1 - Relationship of the advantages of participating in a network

\begin{tabular}{|c|c|}
\hline Advantages of the network (international BP) & Advantages of the network (national BP) \\
\hline Improve the competitiveness & Exchange of information's \\
\hline Increase the market share & Joint programs of training \\
\hline Increase the use of assets & Joint participation in fairs \\
\hline Improve customer service & Realization of joint projects \\
\hline Decrease of the delivery deadline & Improvement of the product \\
\hline Decrease of customer complaints & Search of new markets \\
\hline Share and cost reduction & Costs reduction \\
\hline Joint development of products & Increase of sales \\
\hline Acquisition of technological gain & Joint development of new products \\
\hline Increase of product quality & Improvement of internal processes \\
\hline Improvement of skills and knowledge's & Increase of the productive capacity \\
\hline Acquisition of scale economy & Participation in innovation processes \\
\hline Reduction of stocks & Improvement of the enterprises' image \\
\hline Rapid access to markets & Joint purchase \\
\hline Acquisition of advantages of educational institutions & Access to new markets \\
\hline Increase of presence in the market & Control of globalization and concurrence \\
\hline Sharing of resources & Increase of competition \\
\hline Exchange of information's & Increase of specialization \\
\hline Critical mass increase & Increase of bargaining power \\
\hline Joint production & Exchange of experiences \\
\hline Increase of the innovation capacity & Access to government programs \\
\hline Increase of specialization & Development of new abilities \\
\hline Increase of collective efficiency & Overcome of financial/human limitations \\
\hline Increase of specialized workers & Gain of collective efficiency \\
\hline Joint participation in fairs & Leverage of profitability \\
\hline Funding for joint projects & Access to specialized workers \\
\hline
\end{tabular}

Source: Elaborated by the authors.

From the information presented in Figure 1, is possible to make up a comparison of them: it appears that the advantages listed by the researchers who published articles on SMEs networks are congruent and complementary, that is, the main advantages listed in the articles published in international journals are also listed in national journals. The advantages are mainly related to improvements in the internal context of enterprises, such as management aspects, inventory reduction, asset utilization, funding for joint projects, reduction of costs. External improvements inherent to the market are also visible: bargain with suppliers, customer service, reaching new markets, access to specialized workers, participation in fairs. Thus, it is 
understood that Figure 1 can consolidate the main advantages of participating in a cooperation network in the view of authors who have published in international and national journals.

After the consolidation of the advantages of being part of a network of SMEs by the sight of publications conducted in international and national journals, it was possible to identify the advantages related to the external context and internal to organizations. Regarding the external context, there were considered the advantages related to the performance of the enterprise towards the market and stakeholders, and in relation to the internal context, there were considered the advantages inherent to internal processes, efficiency and internal effectiveness and the relationship between the individual enterprises participants in the cooperation network.

Figure 2 presents the comparison between the advantages of being part of a network of SMEs identified in articles published in national and international journals, related to the external context.

Figure 2 - Advantages of participating of a network of SMEs (external context)

\begin{tabular}{|l|}
\hline $\begin{array}{c}\text { Advantages identified in the articles published in in } \\
\text { international journals (external context) }\end{array}$ \\
\hline Increase of market share \\
\hline Increase of specialized workers \\
\hline Improve competition \\
\hline Greater presence in the market \\
\hline Get rapid access to markets \\
\hline Acquisition of advantages of educational institutions \\
\hline Improvement of customer service \\
\hline Reduce delivery deadline \\
\hline Reduce customer complaints \\
\hline Funding for joint projects \\
\hline
\end{tabular}

Source: Elaborated by the authors.

It is perceived, in Figure 2, that part of the advantages (grey colour) are aspects considered by the authors who published articles in national and international journals, which indicates some convergence on the advantages over the external context to enterprises participating in a network of companies. Most of these convergence advantages are related to participation in higher market share, by revenue growth, market consolidation and opening of new markets. It is also noteworthy the convergence on the increase and improvement of competitiveness and of access to specialized workers.

However, it is perceived that some of the advantages of the external context are identified only in articles published in national or international journals, such as, the increase of the bargaining power, the access to government programs and the improvement of the enterprise' image appears only in articles published in national journals. On the other hand, taking advantage of educational institutions and research, improve customer service, reduce the delivery time, reduce customer complaints and the possibility of seeking funding for joint projects appears in articles published in international journals.

Figure 3 shows the comparison between the advantages of being part of a network of SMEs identified in articles published in national and international journals related to internal context. 
Figure 3 - Advantages of joining a network of SMEs (internal context)

\begin{tabular}{|l|}
$\begin{array}{c}\text { Advantages identified in articles published in } \\
\text { international journals (internal context) }\end{array}$ \\
\hline Increase of the use of assets \\
\hline Increase of collective efficiency \\
\hline Increase specialization \\
\hline Increase of critical mass \\
\hline Increase of product quality \\
\hline Increase of innovation capacity \\
\hline Share and reduce costs \\
\hline Share resources \\
\hline Joint development of products \\
\hline Improve skills and knowledges \\
\hline Joint participation in fairs \\
\hline Exchange informations \\
\hline Produce jointly \\
\hline Reduce stocks \\
\hline Acquire scale economy \\
\hline Acquire technological gain \\
\hline
\end{tabular}

Source: Elaborated by the authors.

It is perceived in Figure 3, that some of the advantages (grey colour) are aspects that are considered by the authors who published papers in national and international journals, which indicates some convergence on the advantages over the internal context to enterprises participating in a network of enterprises. Most of these convergent advantages are related to the gain of collective efficiency, increased specialization, exchange experiences, improvement of products, joint projects of innovation, cost reduction, sharing of resources and information exchange.

However, it is also perceived that some of the advantages of the internal context are identified only in articles published in national or international journals, for example, purchase jointly, improve internal processes, overcome resource constraints and leveraging profitability only appear in articles published in national journals. On the other hand, produce jointly, reduce inventories, obtain scale economies and technology gain appear in articles published in international journals.

\section{FINAL REMARKS}

This research aimed to answer the following research question: What are the advantages pointed out in the national and international literature for Small and Medium Enterprises to join a network of cooperation? The study could answer the question as consolidated the advantages from the researchers' perspective who published articles in national (Brazil) and international journals.

The aim of this study was to map the major studies of networks on SMEs in order to consolidate the different views on the advantages of joining a network of enterprises. This was achieved through three specific objectives. The first, was to conduct a structured process to select the articles more closely aligned with the research topic that was presented in the Procedures for bibliographic search subsection, which clarifies the 
followed path to select the articles (21 published in international journals and 33 published in journals national) that formed the researched bibliographic portfolio.

The second specific objective was to consolidate the main advantages of joining a network of enterprises from the perspective of the authors who have published articles in national and international journals. This goal was achieved and demonstrated from the information contained Figure 1, where are cited the gains in management aspects, joint development of new products, cost reduction, access to new markets, access to specialized workers.

And the third objective was to compare the advantages related to internal and external organizational context of national and international publications. Figures 2 and 3 identify the internal advantages (gain of collective efficiency, increase of specialization, exchange of experiences, improvement of products, joint projects of innovation, cost reduction, etc..) and external (higher participation in market share by revenue growth, market consolidation and opening of new markets, etc..) that are converging between the publications and the advantages that are not convergent, that is, which have been pointed out only by authors who have published in national or international journals

From the results, it is argued that participating in a cooperation network (i) brings important benefits to the competitiveness of enterprises (BITITCI et al., 2007); (ii) allows to overcome the limitations inherent to a SME (BITITCl et al., 2004; GEROLAMO et al., 2008; HANNA; WALSH, 2008); (iii) provides greater stability to the enterprises and these gains do not always have measurable results in economic and financial terms (ANTONELLI; CAROLEO, 2011).

This work present as limitations: (i) the absence of the comparison of literature with practical situations of enterprises that operate individually and in network, (ii) the use of subjectivity in some stages of the selection of articles to form the bibliographic portfolio, and (iii) absence in the study of literature search inherent to the mentioned disadvantages by the researchers regarding the inclusion of SMEs in collaborative networks. Thus, it is pointed out for future works: (i) consult network managers to check the alignment between literature and practice, (ii) consulting enterprises that work individually and enterprises that operate in the network to verify the perception of relevance about the advantages listed in this study, and (iii) to identify in the literature the disadvantages of participating in a network of SMEs, to compare with the advantages identified in this study.

\section{REFERENCES}

ADAM, C. R.; OLIVEIRA, J. H. R.; SCHMIDT, S. Proposição de indicadores para avaliação de desempenho de redes de cooperação gaúchas. Redes: Revista do Desenvolvimento Regional, [S. I.], v. 13, n. 3, p. 218-240, 2008.

AFONSO, M. H. F.; SOUZA, J. V.; ENSSLIN, S. R.; ENSSLIN, L. Como construir conhecimento sobre o tema de pesquisa? Aplicação do processo Proknow-C na busca de literatura sobre avaliação do desenvolvimento sustentável. RGSA - Revista de Gestão Social e Ambiental, [S. I.], v. 5, p. 47-62, 2011.

ANTONELLI, D.; CAROLEO, B. An integrated methodology for the analysis of collaboration in industry networks. Journal of Intelligent Manufacturing, [S. I.], v. 23, n. 6, p. 2443-2450, 2012.

BITITCI, U. S.; MARTINEZ, V.; ALBORES, P.; PARUNG, J. Creating and managing value in collaborative networks. International Journal of Physical Distribution \& Logistics Management, v. 34, n. 3, p. 251-268, 2004.

BITITCI, U. S.; TURNER, T.; MACKAY, D.; KEARNEY, D.; PARUNG, J.; WALTERS, D. Managing synergy in collaborative enterprises. Production Planning \& Control, [S. I.], v. 18, n. 6, p. 454-465, 2007.

BORTOLUZZI, S. C.; ENSSLIN, S. R.; ENSSLIN, L. Avaliação de desempenho dos aspectos tangíveis e intangíveis da área de mercado: estudo de caso em uma média empresa industrial. Revista Brasileira de Gestão de Negócios (RBGN), [S. I.], v. 12, n. 37, p. 425-446, 2010. 
BORTOLUZZI, S. C.; ENSSLIN, S. R.; ENSSLIN, L. Avaliação de desempenho multicritério como apoio à gestão de empresas: aplicação em uma empresa de serviços. Gestão \& Produção, [S. I.], v. 18, n. 3, p. 633-650, 2011a.

BORTOLUZZI, S. C.; ENSSLIN, S. R.; ENSSLIN, L.; VALMORBIDA, S. M. I. A Avaliação de desempenho em redes de pequenas e médias empresas: estado da arte para as delimitações postas pelo pesquisador. R. Eletr. Estrat. Neg, [S. I.], V. 4, n. 2, p. 202-222, 2011 b.

BRUNA JUNIOR, E. D.; ENSSLIN, L.; ENSSLIN, S. R., Seleção e análise de um portfólio de artigos sobre avaliação de desempenho na cadeia de suprimentos. GEPROS: Gestão da Produção, Operações e Sistemas, [S. I.], v. 7, n. 1, p. 113-125, 2012.

BURLAT, P.; BESOMBES, B.; DESLANDRES, V. Constructing a typology for networks of firms. Production Planning \& Control, [S. I.], v. 14, n. 5, p. 399-409, 2003.

CAMARINHA-MATOS, L. M.; ABREU, A. Performance indicators for collaborative networks based on collaboration benefits. Production Planning \& Control, [S. I.], v. 18, n. 7, p. 592-609, 2007.

CAMPO, C. H. G.; ALBARRACíN, E. J. G. Modelo de Emprendimiento en Red - MER. Aplicación de las teorías del emprendimiento a las redes empresariales. Academia - Revista Latinoamericana de Administración, n. 40, p. 13-31, 2008.

CARPINETTI, L. C. R.; OIKO, O. T. Development and application of a benchmarking information system in clusters of SMEs. Benchmarking: An International Journal, [S. I.], v. 15, n. 3, p. 292 306, 2008.

CARPINETTI, L. C. R.; GALDÁMEZ, E. V. C.; GEROLAMO, M. C. A measurement system for managing performance of industrial clusters: A conceptual model and research cases. International Journal of Productivity and Performance Management, [S. I.], v. 57, n. 5, p. 405-419, 2008.

CARPINETTI, L. C. R.; GEROLAMO, M. C.; GALDÁMEZ, E. V. C. Continuous Innovation and Performance Management of SME Clusters. Creativity and Innovation Management, [S. I.], v. 16, n. 4, p. 376-385, 2007.

$\mathrm{CHAO}, \mathrm{Y}-\mathrm{C}$. Decision-making biases in the alliance life cycle: Implications for alliance failure. Management Decision, [S. I.], v. 49, n. 3, p. 350-364, 2011.

DAMASKOPOULOS, T.; GATAUTIS, R.; VITKAUSKAITE, E. Extended and dynamic clustering of SMEs. Engineering Economics, [S. I.], v. 1, n. 56, p. 11-21, 2008.

FACCIN, K.; GENARI, D.; DORION, E.; MACKE, J. Capital Social: recurso estratégico para o desempenho de redes organizacionais. Aríus - Revista de Ciências Humanas e Artes, [S. I.], v. 15, n. 2, p. 9-23, 2009.

FARIAS, A. S. D.; RAMOS, F. S. Cooperação Empresarial: estudo de caso em uma rede de empresas organizada na forma de cooperativa. Aríus - Revista de Ciências Humanas e Artes, [S. I.], v. 15, n. 2, p. 27-41, 2009.

GALÃO, F. P.; CAMARA, M. R. G. Inovação e orientação para o mercado e desempenho no arranjo produtivo local embrionário do vestuário de Londrina/PR. Revista de Ciências da Administração, [S. I.], v. 11, n. 23, p. 87-11, 2009.

GALDÁMEZ, E. V. C.; CARPINETTI, L. C. R.; GEROLAMO, M. C. Proposta de um sistema de avaliação do desempenho para arranjos produtivos locais. Gestão \& Produção, [S. I.], v. 16, n. 1, p. 133-151, 2009.

GEROLAMO, M. C.; CARPINETTI, L. C. R.; SELIGER, G.; GALDÁMEZ, E. V. C. Performance management of regional clusters and SME cooperation networks. International Journal of Business Excellence, [S. I.], v. 1, No.4, p. 457-483, 2008.

GIL, A. C. Como elaborar projetos de pesquisa. São Paulo: Atlas, 1999.

GOBBO JUNIOR, J. A.; VASCONCELLOS, M. A.; SALGADO, M. H.; CASTRO, R. Abordagem metodológica de investigação das redes interfirmas sob a perspectiva de estratégia de operações. GEPROS - Gestão da Produção, Operações e Sistemas, [S. I.], v. 2, n. 1, p. 11-23, 2006.

GRANDO, A.; BELVEDERE, V. District's manufacturing performances: A comparison among large, small-to-mediumsized and district enterprises. International Journal of Production Economics, [S. I.], v. 104, n. 1, p. 85-99, 2006.

HANNA, V.; WALSH, K. Interfirm cooperation among small manufacturing firms. International Small Business Journal, [S. I.], v. 26, n. 3, p. 299-321, 2008.

HANSEN, P. B.; OLIVEIRA, L. R. Proposta de modelo para avaliação sistêmica do desempenho competitivo de arranjos produtivos: o caso do arranjo coureiro calçadista do Vale dos Sinos (RS - Brasil). Produto \& Produção, [S. I.], v. 10, n. 3, p. 61-75, 2009.

HOFFMANN, W. H.; SCHLOSSER, R. Success factors of strategic alliances in small and medium-sized enterprises an empirical survey. Long Range Planning, [S. I.], v. 34, n. 3, p. 357-381, 2001.

JÄHN, H. Value-added process-related performance analysis of enterprises acting in cooperative production structures. Production Planning \& Control, v. 20, n. 2, p. 178-190, 2009.

LACERDA, R. T. O.; ENSSLIN, L.; ENSSLIN, S. R. A performance measurement framework in portfolio management: a constructivist case. Management Decision, [S. I.], v. 49, n. 4, p. 648-668, 2011. 
LACERDA, R. T. O.; ENSSLIN, L.; ENSSLIN, S. R. Uma análise bibliométrica da literatura sobre estratégia e avaliação de desempenho. Gestão \& Produção, [S. I.], v. 19, n. 1, p. 59-78, 2012.

MAIS, I.; CARVALHO, L. C.; AMAL, M.; HOFFMANN, M. G. Importância das redes nos processos de inovação e internacionalização de empresas de base tecnológica. Revista de Administração e Inovação, [S. I.], v. 7, n. 1, p. 41-61, 2010.

MARION FILHO, P. J.; SONAGLIO, C. M. Inovações tecnológicas na indústria de móveis: uma avaliação a partir da concentração produtiva de Bento Gonçalves (RS). Revista Brasileira de Inovação, [S. I.], v. 9, n. 1, p. 93-118, 2010.

MARTINKENAITE, I. Antecedents and consequences of inter-organizational knowledge transfer: Emerging themes and openings for further research. Baltic Journal of Management, [S. I.], v. 6, n. 1, p. 53-70, 2011.

MARTINS, Daniel de Araújo; GUERRA, Lenin Cavalcanti Brito; SANTOS, Esmeraldo Macedo dos; CAMPOS, Ana Járvis de Melo; FORBELONI, Jacimara Villar; FEITOR, Carlos Cerqueira. Arranjos Produtivos Locais: contribuições para uma análise longitudinal e complexa dos aspectos estratégicos. In: ENCONTRO DA ASSOCIAÇÃO NACIONAL DE PÓSGRADUAÇÃO E PESQUISA EM ADMINISTRAÇÃO, 33., 2009, São Paulo. Anais... São Paulo: ANPAD, 2009. p. 1-15.

MAZZARO, L. G.; OLIVA, F. L.; GRISI, C. C. H.; DROUVOT, H.; CRISPIM, S.; GASPAR, M. A. A competitividade nos clusters da indústria de borracha do sudeste asiático. Revista de Ciências da Administração, [S. I.], v. 11, n. 23, p. 6586, 2009.

MONDO, T. S.; FIATES, G. G. S. Mapeamento bibliométrico dos modelos de qualidade em serviços: publicações de pesquisadores brasileiros sobre o tema até 2012. Revista Pretexto, Belo Horizonte, v. 15, n. 1, p. 11-28, 2014.

NASCIMENTO, S.; BORTOLUZZI, S. C.; COELHO, A. L. L.; COELHO, C.; ENSSLIN, S. R. Ferramentas gerenciais à luz do desempenho organizacional. Revista Pretexto, Belo Horizonte, v. 11, n. 3, p. 34-57, 2010.

PARRILLI, M. D. Collective efficiency, policy inducement and social embeddedness: Drivers for the development of industrial districts, Entrepreneurship \& Regional Development, [S. I.], v. 21, n. 1, p. 1-24, 2009.

PEREIRA, B. A. D.; VENTURINI, J. C. Identificação dos fatores determinantes do desempenho das empresas inseridas em redes horizontais. Revista de Ciências da Administração, [S. I.], v. 8, n. 16, p. 260-279, 2006.

PETTAN, K. B. Análise comparativa do desempenho da competitividade das agroindústrias familiares no Oeste de Santa Catarina em relação ao ambiente institucional. Cadernos de Ciência \& Tecnologia, [S. I.], v. 22, n. 3, p. 667-689, 2005.

PORTER, M. Clusters and the new economy of competition. Harvard Business Review, [S. I.], v. 76, v. 6, p. 77-91, 1998.

REZENDE, O.; SERPA, C. A. Análise do desempenho de um grupo exportador de cosméticos sob a perspectiva empresarial: um estudo de caso do grupo Minas Beauty. Internext - Revista Eletrônica de Negócios Internacionais ESPM, [S. I.], v. 4, n. 1, p. 79-99, 2009.

RICHARDSON, R. J. Pesquisa social: métodos e técnicas. São Paulo: Atlas, 2008.

ROSA, F. S.; ENSSLIN, S. R.; ENSSLIN, L.; LUNKES, R. J. Evidenciação ambiental para gestão interna: um estudo sobre as potencialidades e oportunidades do tema. Engenharia Sanitária e Ambiental, [S. I.], v. 16, n. 2, p. 157-166, 2011.

SILVA, C. E. L.; HEWINGS, G. J. D. A decisão sobre investimento em capital humano em um arranjo produtivo local (APL): uma abordagem teórica. Revista Brasileira de Economia, [S. I.], v. 64, n.1, p. 67-79, 2010.

SOUZA, C. A. V.; FERRAZ, F. T. Fatores críticos de sucesso no desempenho de um polo: o caso do APL de indústrias de vestuário de Muriaé-MG. Boletim Técnico Organização \& Estratégia, [S. I.], v. 3, n. 3, p. 302-320, 2007.

SUZIGAN, W. Aglomerações industriais, como focos de políticas. Revista de Economia Política, [S. I.], v. 21, n. 3, p. 2839, 2001.

TASCA, J. E.; ENSSLIN, L.; ENSSLIN, S. R.; ALVES, M. B. M. An approach for selecting a theoretical framework for the evaluation of training programs. Journal of European Industrial Training, [S. I.], v. 34, n. 7, p. 631-655, 2010.

VERSCHOORE, J. R.; BALESTRIN, A. Fatores relevantes para o estabelecimento de redes de cooperação entre empresas do Rio Grande do Sul. RAC - Revista de Administração Contemporânea, [S. I.], v. 12, n. 4, p. 1043-1069, 2008.

VILLA, A. Analyzing industrial district performances: A structured approach. Annual Reviews in Control, [S. I.], v. 31, n. 1, p. 107-118, 2007.

WEGNER, D.; MISOCSKY, M. C. Avaliação de desempenho de redes de pequenas empresas: contribuições da abordagem da produção de sentido. Revista O\&S, [S. I.], v. 17, n. 53, p. 456-361, 2010.

WELSH, J. A.; WHITE, J. F. A Small Business is not a Little Big Business. Harvard Business Review, [S. I.], v. 59, n. 4, p. 18-27, 1981. 